\title{
Relations Between Parent's Attention and Learning Motivation With Social Science Learning Outcome
}

\author{
A Zaenal Abidin* \\ Elementary School Teacher Education Department \\ Universitas Negeri Semarang \\ Semarang, Indonesia \\ zaenrkt@mail.unnes.ac.id \\ Galih Mahardika Christian Putra \\ Elementary School Teacher Education Department \\ Universitas Negeri Semarang \\ Semarang, Indonesia \\ galihputra@mail.unnes.ac.id
}

\author{
Dyah Rachmadani \\ Elementary School Teacher Education Department \\ Universitas Negeri Semarang \\ Semarang, Indonesia \\ janahdyahrachmadani@gmail.com
}

\author{
Deni Setiawan \\ Elementary School Teacher Education Department \\ Universitas Negeri Semarang \\ Semarang, Indonesia \\ deni.setiawan@mail.unnes.ac.id
}

\begin{abstract}
The purpose of this research was to find out the correlation between parents' attention and learning motivation to learning outcome. This study included quantitative research with correlational design with a sample of 113 students from a population of 140 using simple random sampling. The results of data analysis with the data prerequisite test obtained were normal data, linear data, and nomulticollinearity. The techniques of data analysis used a descriptive statistics, simple correlations, multiple correlations, simple regression, and multiple regression. The results showed parents' attention and learning motivation had a positive relationship with social studies learning outcomes with a contribution of $47.7 \%$. Conclusions in this study were there is a positive correlation between parental attention and learning motivation to social studies learning outcomes of fourth grade of SDN Gugus Dwija Krida, Mijen District, Semarang City.
\end{abstract}

Keywords: Learning Motivation, Parents Attention, Social Studies Learning Outcomes.

\section{INTRODUCTION}

Education is the essence of the values of the experiences and beliefs of society as well as the culture, so it can develop the students into the intelligent, creative, tough, havinggood-character, and responsible person. This is in line with Act of Republic Indonesia (20/2003) on National Education System Chapter I, Article 1, Verse 1 which states that education is the conscious and systematic measures create study and learning atmosphere in order that the students actively develop their potentials in order to have religious and spiritual power, good self-control, high intelligence, good character, as well as good skill needed by himself, his society, his nation, and the country.

Implementation of the education in the learning process should be in accordance with the objectives of national education under Act of Republic Indonesia (20/2003) Chapter II Article 3; which states that national education aims to build the competency and character as well as the dignified civilization, in order to intellectualize the nation, to develop the students' potential in order to become a faithful and righteous man to the one and only God who have good character, who are healthy, knowledgeable, skillful, creative, independent, and responsible.

In an education process, the students comprehend diverse information and culture in an education institution. The education institutions comprise formal institutions carried out in schools and informal institutions carried out in the family and among the society. Although the student study at school every day, the family plays important role in their children's education. It is stated under Act of Republic Indonesia (20/2003) Chapter IV Article 7 on Parents' Right and Duty that the parents are entitled to playing the role in selecting the education institution and to get information about their children's education progress and the parents of the children are obliged to learn and study and are obliged to provide their children with basic education.

In relation to the explanation above, the definition of learning according to Slameto is a process that must be gone through by a man to change their behavior comprehensively as a result of his experiences when interacting with his surroundings and the experiences that he acquires can be the learning outcome during his study at school[1]. The good basic education should be provided to their family members at the early age in order to play the education role and function of the family, i.e. to develop the children's potential, as a tool to transfer the values and for cultural transformation. In addition, parents and teachers need to cooperate to achieve the children's learning success such as the high attention when teaching and building their learning motivation.

According to Darmadi the parents' role as motivator is expected to be able to raise motivation of their children, which means that the attention that their parents pay to them will raise the learning motivation of the students. Motivation is important, not only to make the students do the learning activities, but also to determine how many students can learn from the activities they do or from the information they get[2]. 
Based on the data collected from the interviews and documentation, the researchers got data about the problems in Gugus Dwija Krida District of Mijen, Semarang City, that parents do not pay enough attention to their children's learning process mostly because of their parents' busyness in terms of working. In addition, the students also spent more time in the private lesson place than learning at home. Most of the students also do not like reading the lesson materials of the Social Science subject because of too many lesson materials to learn, so that they have only poor motivation to

learn. It is worsened by minimum usage of the teaching tools and learning media such as the available LCD, so it makes the poor learning outcome for the social science subject, even lower than the Minimum Mastery Criteria. This was shown by the School Final Exam average score of grade IV students of Dwija Krida Primary Schools Group that is below standard, i.e. $49.55 \%$ students did not meet the criteria.

It was confirmed by the previous study conducted by A.Y Soegeng and ZahrotunNisa in 2014 titled Relations between Parents' Attention with Grade IV Students' Learning Outcomes in the Thematic Integrated Learning in SD Negeri Kembangarum 2 Mranggen Demak that shows that based on the assessment, parents' attention (variable $\mathrm{x}$ ) and learning outcome (y variable) has the significant and positive relation (0.996784). Based on such relations, the value of intervariable relation is $31.81 \%$. This means that the learning outcome is affected by parents' attention, while the rest $68.19 \%$ is affected by the other things such as the children's intelligence, parents' parenting style, economic class[3].

Relation between parents' attention with their children learning achievement was also shown in a journal titled "Parent Influence on Outcome for Children: HIPPY as a Cost Effective Option" which states:“... HIPPY ( Home Interaction programme for Parents and Youngsters) has been successfully operated in New Zealand and overseas. HIPPY is a home-based programme that trains parents to help school or later life." That statement shows the success of the HIPPY program in New Zealand that ran well. HIPPY was a program built by the Government to coach the parents to interact with their children by learning together, interacting, and helping their children cope with their difficulties when learning at school.

Based on the explanation above, the researchers outline the problem concerning the relation between parents' attention and learning motivation with the learning outcome especially on social science subject that aims to investigate the relation between learning motivation with learning outcome as well as to find out the role of learning interest in the improvement of Social Science learning outcome of primary school students.

\section{METHODS}

In the study the researchers applied quantitative study by using correlational study as the research design. The research population is 140 grade IV public primary school students of Dwija Krida Group in District of Mijen, Semarang City. The study was conducted in SDN Purwosari 01, SDN Purwosari 02, SDN Karangmalang, and SDN Cangkiran 01. The researchers applied simple random sampling as a sampling method. The research variables are independent variable (parents' attention and learning motivation) and dependent variable (social science learning outcome).

Data for the research were collected through questionnaire fulfillment for parents' attention and learning motivation; documentation of social science learning outcomes; and interviews with teacher, parents, and students for the support. Validity and reliability were assessed before the instruments were used. Those instruments were experimented to the other schools out of the samples in advance to find out the instrument accuracy. There were 27 students used as the experimental respondents. So the value of $r_{\text {count }}$ should be more than $r_{\text {table }}$ which was 0.381 with significance level 5\%. To test validity, the researchers used Pearson Product Moment formula and to test reliability it used SPSS version 21-assisted Alpha Croncbach formula[4].

Data precondition test was in advance conducted by normality test, linearity tes, and multicollinearity test. Then a hypothesis test was conducted comprising simple correlation analysis, multiple correlation analysis, simple linear regression analysis, and multiple regression analysis.

\section{RESULTS AND DISCUSSION}

The research on the relation between parents' attention and children's learning motivation with social science learning outcome of grade IV students of public primary schools in Dwija Krida Group in District of Mijen Semarang City is presented below.

\section{Results}

Descriptive Analysis of Parents' Attention (X1)

The researchers collected data for descriptive analysis of parents' attention from the fulfilled questionnaire containing 27 questions with four answer options based on likert scale. The data processing of the fulfilled questionnaire is presented in the following table:

\section{TABLE I. DATA Descriptive ANALYSIS OF PARENTS' AtTENTION}

\begin{tabular}{|c|c|c|c|c|}
\hline Interval & Criteria & Frequency & $\begin{array}{l}\text { Total } \\
\text { Percentage }\end{array}$ & $\begin{array}{l}\text { Average } \\
\text { Score }\end{array}$ \\
\hline $95-116$ & Excellent & 10 & $9 \%$ & \multirow{4}{*}{82} \\
\hline 73-94 & Good & 65 & $58 \%$ & \\
\hline $51-72$ & Fair & 38 & $34 \%$ & \\
\hline $29-50$ & Poor & 0 & $0 \%$ & \\
\hline Total & & 113 & $100 \%$ & Good \\
\hline
\end{tabular}

Source: data processed in 2019

Table 1 shows that the distribution of parents' attention frequency is included in "excellent" category for 26 students (23\%), "good" criteria for 63 students $(56 \%)$, "fair" criteria for 24 students $(21 \%)$, and "poor" criteria for 0 students $(0 \%)$.

\section{Descriptive Analysis of Learning Motivation (X2)}

Data for descriptive analysis of learning motivation were collected from fulfilled questionnaire containing 29 questions with four answer options based on likert scale. The data processing output of the fulfilled questionnaire is presented in the following table: 
TABLE II. DATA FOR DESCRIPTIVE ANALYSIS OF LEARNING MOTIVATION

\begin{tabular}{|c|c|c|c|c|}
\hline Interval & Criteria & Frequency & $\begin{array}{l}\text { Total } \\
\text { Percentage }\end{array}$ & Ave-rage \\
\hline 88-108 & Excellent & 26 & $23 \%$ & \multirow[t]{4}{*}{$\begin{array}{l}78 \\
\text { (Good) }\end{array}$} \\
\hline $68-87$ & Good & 63 & $56 \%$ & \\
\hline $48-67$ & Fair & 24 & $21 \%$ & \\
\hline $27-47$ & Poor & 0 & $0 \%$ & \\
\hline \multicolumn{2}{|c|}{ Total } & 113 & $100 \%$ & \\
\hline
\end{tabular}

Source: data processed in 2019

Table II shows that from frequency distribution of data for learning motivation 10 students meet criteria of "excellent" category $(9 \%), 65$ students meet criteria of "good" category (58\%), 38 students meet criteria of "fair" category $(34 \%)$, dan $(0 \%) 0$ student meet criteria of "poor" category.

\section{Descriptive Analysis of Social Science Learning Outcome} (Y)

Data of students' learning outcome were collected from the scores of the Mid-term Test categorized under Regulation of Ministry of Education and Culture. The data processing output of the Social Science learning outcome is presented in the following table.

TABLE III. TABLE TYPE STYLES

\begin{tabular}{|l|l|l|l|l|}
\hline Score & Category & Frequency & Percentage & Average Score \\
\hline $86-100$ & Excellent & 37 & $33 \%$ & 75 \\
\cline { 1 - 3 } $71-85$ & Good & 44 & $39 \%$ & \\
\cline { 1 - 3 } $56-70$ & Fair & 32 & $28 \%$ & \\
\cline { 1 - 3 }$\leq 55$ & Poor & 0 & $0 \%$ & \\
\cline { 1 - 3 } Total & & 113 & $100 \%$ & Good \\
\hline
\end{tabular}

Source: data processed in 2019

Table 3 shows that from learning outcome frequency data distribution 37 students meet criteria of "excellent" category (33\%), 44 students meet criteria of "good" category (39\%), 32 students meet criteria of "fair" category $(28 \%)$, dan $(0 \%)$ 0 student meet criteria of "poor" category.

\section{Discussion}

\section{Data Analysis Precondition Test}

\section{Data Normality Test}

The test was conducted to find out if data of parents' attention, learning motivation, and Social Science learning outcome were normally distributed or they were not. The normality test was conducted by being assisted by SPSS version 21 using liliefors method as assessment method using Kolmogorov-Smirnov, and from the test I got the output with significance level 0.71 for parents' attention, 0.173 for learning motivation, and 0.58 for Social Science learning outcome. The researchers, therefore, can draw a conclusion that data for parents' attention, learning motivation, and learning outcome as variables are distributed normally because their significance levels are more than 0.05 .

\section{Data Linearity Test}

Linearity test is usually used to find out if there is linear relation between two variables of research data or there is not. The test was SPSS-assisted one with test for linearity at significance social science learning outcome was level 0.05 . The output of the linearity test of relation between parents' attention and 0.137 and of relation between learning motivation with social science learning outcome was 0.387 . Based on the thing above, the researchers conclude that parents' attention and learning motivation have linear relation with Social Science learning outcome because its significance level was 0.05 .

\section{Data Multicollinearity Test}

Multicollinearity test is used to find out if in regression model there was intervariable close relation. The test was SPSS version 21-assisted one. The criteria for the outputs are if value of VIF is below 10 dan tolerance rate is more than 0.1 then there is not multicollinearity relation. The output was that tolerance rate of parents' attention was 0.633 and the value of VIF was 1.580 while tolerance rate of learning motivation was 0.633 the value of VIF was 1.580 . Based on the explanation above, the researchers can conclude that there is not any multicollinearity relation because in the output, the tolerance rate was more than 0.1 and the value of VIF was below 10 .

\section{Hypothesis Test}

\section{Simple Correlational Test}

Hypothesis test analysis is used to test the hypothesis of the research that the researchers have made in the study. The formula that the researchers used was formula to calculate Product Moment Correlation.

TABLE IV. OUTPUT OF PRODUCT MOMENT CORRELATION CAlCulation

\begin{tabular}{|l|l|l|l|l|}
\hline Variable & Sig & $\begin{array}{l}\text { Pearson } \\
\text { correlation }\end{array}$ & $r_{\text {table }}$ & r Category \\
\hline$X_{1}$ and $\mathrm{Y}$ & 0.000 & 0.646 & 0.183 & Strong \\
\hline$s X_{2}$ and $\mathrm{Y}$ & 0.000 & 0.739 & 0.183 & Strong \\
\hline
\end{tabular}

Source: data processed in 2019

Table 4 explains that in $X_{1}$ and Y parts, value of $r_{\text {count }}$ is bigger than $\mathrm{t}_{\text {table }},(0.646>0.183)$. It also was going positive way because the value of $r$ output was positive, which means that the more positive or the better the parents' attention is, the higher the students' Social Science learning outcome is. If the correlation coefficient is between 0.600-0.799, then it has strong relation. The researchers, therefore, can conclude that parents' attention has strong relation with Social Science learning outcomes. While in $X_{2}$ and $\mathrm{Y}$ parts, we can see that $r_{\text {count }}$ is more than $r_{\text {table }}(0.739>0.183)$. It means that $\mathrm{H}_{0}$ is rejected and $\mathrm{Ha}$ is accepted. The conclusion is that learning motivation has positive relation with social science learning outcome. It also went the positive way because the value of $r$ output was positive Arah yang didapatkan juga positif, because the value of $r$ obtained is positive, which means that the more positive and the higher the learning motivation, the better social science learning outcome. If the correlation coefficient is between 0.600-0.799 then they have strong relation. Thus, the conclusion is that learning motivation has strong relation with social science learning outcome. 
The supporting study is the one conducted by Rofiqul A'la titled Parents' Attention and Learning Motivation shows that SMP Negeri 01 Pemalang students' parents' attention is high (91\%), high learning motivation (59\%), and parents' attention has impact on learning motivation at significance level 0.003 and the value of $F_{\text {count }}$ is 6.211[5]. It is supported by another study conducted by Gunawan in 2015 that shows that motivation has positive and significant impact on students' achievement in SMA 1 Bangsri during 2012/2013 on Economics subject[6].

\section{Multiple Correlation Analysis I}

Multiple correlation, according to Sugiyono (2016:231) is the number that showed the direction and the strength of relation between two or more independent variables with one dependent variable mutually[4]. The calculation output of the multiple correlation test is shown below.

TABLE V. OUtPut OF MUlTiPLE CORRELATION TEST

\begin{tabular}{|l|l|}
\hline Variable & $\mathrm{R}$ \\
\hline $\mathrm{X}_{1}$ and $\mathrm{X}_{2}$ with $\mathrm{Y}$ & $.779^{a}$ \\
\hline
\end{tabular}

Source: data processed in 2019

Table 5 shows that $R_{\text {count }}$ value is more than $r_{\text {table }}$ value $(0.779>0.189)$. If the correlation coefficient is between $0.600-0.799$, then the intervariable relation is strong. Thus, the conclusion is that parents' attention, learning motivation, and Social Science learning outcome have strong relation.

As Darmadi stated (2017) parents' role as motivator must be able to encourage their children's motivation, which means that they must pay great attention to their children at home in order to be encouraged to learn hard. The encouragement depends on how much attention their parents pay to them. If they pay big attention, it will encourage the emerging motivation inside the children to achieve the good learning outcome, vice-versa[2].

Then it is supported by the study conducted by Dimas Qondias titled Relation between Motivation with social science learning outcome, which shows that motivation to have achievement has direct relation with Social Science learning outcome, i.e. $16.9 \%$ in which $(r=0.412 ; \rho=0.016)$. This shows that motivation makes direct contribution to social science learning outcome[7].

\section{Simple Linear Regression Analysis}

Ridwan (2013: 147) defines simple regression as a process of systematic prediction about what is most likely to take place in the future. The output of simple linear regression analysis is presented in the following table[8].

TABLE VI. OUtPUT OF SIMPLE LINEAR REGRESSION ANALYSIS

\begin{tabular}{|l|l|l|l|}
\hline Variables & R Square & Sig & Keterangan \\
\hline$X_{1}$ and Y & 0.417 & 0.000 & $\begin{array}{l}\text { Significant,41. } \\
7 \%\end{array}$ \\
\hline$X_{2}$ dan Y & 0.545 & 0.000 & $\begin{array}{l}\text { Significant,54. } \\
5 \%\end{array}$ \\
\hline
\end{tabular}

Souce: data processed in 2019

Based on table VI, we can see that the relation between parents' attention and social science learning outcome makes contribution about $41.7 \%$ at significance level 0.000 which is less than 0.05 and the contribution of the relation between learning motivation with social science learning outcome is $54.5 \%$ at significance level 0.000 which is less than 0.05 . So, the researchers can conclude that if the significance level is 0.000 or less than 0.05 , it means that parents' attention has significant impact on social science learning outcome, i.e. $41.7 \%$ and learning motivation makes contribution to social science learning outcome, i.e. $51.1 \%$, while the remainder is influenced by the other things.

\section{Multiple Regression Analysis}

Multiple regression in the study aims to predict the dependent variable (Y) if independent variable $(\mathrm{X})$ is identified (Ridwan, 2013:147). The calculation of multiple linear regression analysis is shown in the following table[8].

TABLE VII. CALCUlation OF Multiple LinEAR REgRESSION ANALYSIS

\begin{tabular}{|l|l|l|l|l|}
\hline Variables & R Square & Sig. & $\begin{array}{l}\text { Regression } \\
\text { Coefficient }\end{array}$ & Constant \\
\hline $\mathrm{X}_{1}$ and $\mathrm{X}_{2}$ with $\mathrm{Y}$ & $\begin{array}{l}0.608 \\
(60.8 \%)\end{array}$ & 0.000 & $\begin{array}{l}\mathrm{X}_{1}=0.365 \\
\mathrm{X}_{2}=0.571\end{array}$ & -6.080 \\
\hline
\end{tabular}

Source: data processed in 2019

Table VII shows that the relation between parents' attention $\left(\mathrm{X}_{1}\right)$ and learning motivation $\left(\mathrm{X}_{2}\right)$ with social science learning outcome makes contribution about $60.8 \%$, at significance level $0.000<0.05$, regression coefficient for $\mathrm{X}_{1}$ was 0.365 and $\mathrm{X}_{2}$ was 0.571 , and the constant was -6.080 , thus the equation of the regression is $\breve{Y}=-6.080+0.365 \mathrm{X}_{1}+$ $0.571 \mathrm{X}_{2}$. We can conclude that the multiple regression coefficient is significant, which means that parents' attention and learning motivation have significant relation with social science learning outcome i.e. $55.2 \%$. The motivated behavior is the consequence of the previous similar one. If the students get encouragement for doing the certain behavior, they will tend to do it again enthusiastically. Otherwise, they tend to lose their learning interest and make poor performance[9].

\section{CONCLUSION}

Based on the analysis and the explanation in the study, parents' attention and learning motivation have positive and significant relation with social science learning outcome at coeficient about 0.779 . Contribution of parents' attention and learning motivation to social science learning outcome was about $60.8 \%$ and the remaining $39.2 \%$ was influenced by the other factors. From the conclusion, it means that parents' attention and learning motivation have positive and significant relation with social science learning outcome of grade IV students in public primary schools of Dwija Krida Group in District of Mijen, Semarang City.

\section{ACKNOWLEDGEMENT}

The researchers thanked the principals in the Dwija Krida Mijen Cluster, the teachers in the Dwija Krida Mijen Cluster, bestari partners in this writing. A thank you was also conveyed to the Head of the Elementary School Teacher Education Department, Faculty of Education, Universitas Negeri Semarang, who provided support for this research. 


\section{REFERENCES}

[1] Slameto, Belajar dan Faktor-Faktor yang MempengaruhinyaBelajar dan Faktor-Faktor yang Mempengaruhinya. Jakarta: Rineka Cipta, 2010.

[2] Darmadi, Pengembangan Model dan Metode Pembelajaran dalam Dinamika Belajar Siswa. 2017.

[3] A. d. Z. N. Soegeng, "Hubungan antara Perhatian Orang Tua dan Hasil Belajar pada Pembelajaran Tematik Integratif Siswa Kelas IV SD Negeri Kembangarum 2 Mranggen Demak," J. Empati, Univ. PGRI Semarang, vol. 2, no. 2, 2014.

[4] Sugiyono, "Metode Penelitian Pendidikan Pendekatan Kuantitatif, Kualitatif, dan R\&D," alfabeta, 2016.

[5] R. A'la, "Perhatian orang tua dan motivasi belajar siswa," J. Madaniyah, vol. 2, no. 11, 2016.

[6] F. R. Gunawan, "Lingkungan Keluarga dan Motivasi terhadap Prestasi Belajar Siswa Ekonomi Kelas XI IPS SMA 1 Bangsri 2012/2013," Econ. Educ. Anal. J., vol. 4, no. 2, 2015.

[7] D. Qondias, "Determinasi Motivasi terhadap Hasil Belajar IPS," J. Pendidik. Dasar, vol. 3, no. 1, p. 271, 2017.

[8] Ridwan, Belajar Mudah Penelitian untuk Guru-Karyawan dan Peneliti Pemula. Bandung: Alfabeta, 2013.

[9] R. Juniar, "The Role of Motivation in Learning English for Indonesian Students,” Int. J. Manag. Appl. Sci., vol. 2, no. 8, p. 67, 2009. 